\title{
Assessment of food frequency for diabetic patients after coronary artery bypass graft at ibn al-bitar specialized center for cardiac surgery in Baghdad city
}

\begin{abstract}
Diabetes is a serious public health problem with serious secondary complications, one of these problems are coronary artery disease. The global burden of diabetes is large and growing, affecting populations in every region of the world.

Objective: To assess the diabetic patients dietary habits and find out the relationship between these patients food frequency and their socio-demographic characteristics of. age, gender, marital status, and economic status.

Methodology: A descriptive analytical study was conducted on Non-probability (purposive sample) of (100) a diabetic patients at (Ibn Al-Bitar specialized center for cardiac surgery).in Baghdad City A questionnaire was used as a tool of data collection for the period of $12^{\text {th }}$ May to $12^{\text {th }}$ July 2016. Descriptive statistical analyses were used to analyze the data.
\end{abstract}

Results: The results of the study shows that the majority of the age group were (6069 ) years old (41\%). Most of the study samples (73\%) were male. Most of them $(69 \%)$ were married and $(62 \%)$ the test of (HbA1c) indicates more than seven. More than study samples $(91 \%)$ do not follow the diet program.

Conclusion: The study results indicate highly significant differences association between age group with knowledge of the dietary habits. There is indicated that high significant association between marital status and dietary habits high significant differences association between marital statuses food frequency which are more frequent among married patients.

Recommendation: Diabetes self-management education (DSME) and support (DSMS) programs are appropriate for education and support to develop and maintain behaviors that can prevent diabetes, perform the A1C test at least two times a year in patients who are meeting treatment goals, In adults, a screening lipid profile is reasonable at the time of first diagnosis, at the initial medical evaluation twice yearly.

Keywords: assessment, diabetic patients, food frequenc, coronary artery bypass graft
Volume 5 Issue I - 2018

Saad M Abdulhameed, Khalida M Khudur

Department of Adults Nursing, College of Nursing, University of Baghdad, Iraq

Correspondence: Khalida M Khudur, Department of Adults Nursing, College of Nursing, University of Baghdad, Iraq, Email kdalida_mohammed@yahoo.com

Received: April 21, 2017| Published: January 09, 2018

\section{Introduction}

All forms of diabetes increase the risk of long-term complications. These typically develop after many years (10-20), but may be the first symptom in those who have otherwise not received a diagnosis before that time. ${ }^{1}$ The major long-term complications relate to damage to blood vessels. Diabetes doubles the risk of cardiovascular disease and about $75 \%$ of deaths in diabetics are due to coronary artery disease. ${ }^{2}$

The role of nutrition in maintaining health and reducing the damage caused by diabetes and atherosclerosis heating helps keep your blood glucose, also called blood sugar, in the target range. Physical activity and, if needed, diabetes medicines also help. ${ }^{3}$ One of the risk factor for the development of coronary artery disease is diabetes mellitus is approximately $20 \%$ to $30 \%$ of the patients undergoing Coronary Artery Bypass Graft (CABG) have diabetes mellitus There is not enough evidence to determine the impact of DM on short-term mortality and morbidity in the patients undergoing $\mathrm{CABG} .{ }^{4}$ Cardiovascular disease is the most common cause of mortality. Each year it accounts for 30\% of deaths worldwide and $38.5 \%$ in the United States and Europe. Although the incidence of cardiovascular disease is decreasing in high-income countries due to education and advancement in medical therapy, it is rapidly rising in middle- and low-income countries as they become increasingly industrialized and urbanized. ${ }^{5}$

\section{Methodology}

A descriptive study used to achieve the early stated objectives. The study was done from $23^{\text {rd }}$ February up to $23^{\text {rd }}$ July 2016. In order to obtain an accurate data and a representative sample, nonprobability a purposive sample of (100) diabetic patients in Ibn AlBitar specialized center for cardiac surgery were chosen. The data were collected in the period from $12^{\text {th }}$ May to $12^{\text {th }}$ July_2016. The researcher collected the samples by interview with patients through a special designed questionnaire. This interview took a period of about 10-15 Minutes for each sample. The answers for the third and fourth 
part of the questionnaire rated as (3) for always, (2) for sometimes and (1) for never. The questionnaires was constructed and composed of four parts.

\section{Part I: demographic and socio-economic status}

Consisted of (6) items which included: age, gender, occupation, marital status, (level of education, and Housing expenses such as family type, home type and have a car) to calculate the economic status.

\section{Part medical information}

Second part consists of (11) items. The first item is for Body mass index The second item about smoker, the third item about drinking alcohol, the fourth item about the cumulative rate of sugar $\mathrm{HbAlc}$, the fifth item about the date of diagnosed the diabetes mellitus, the sixth item about the diet without taking treatment, the seventh item about the take tablets for diabetes mellitus, the eighth item about the inject insulin, the ninth item about the take some herbs therapeutic, the tenth item about the history of diagnosis of a blockage in the coronary artery, and the eleven item about the date of coronary artery bypass graft surgery.

\section{Part III: (FFQ) FOOD FREQUENCY QUESTIONERS}

This part includes the food frequency Questioners which Consisted of different categories of food that contain food nutrients, the part consists of (9) domains which include (71) items.

\section{Results}

(Table 1) The analysis of socio-demographic characteristics shows that the more frequent age group is 60-69 years old among the patients $(41 \%)$; two third of the sample are male (71\%). Regarding socioeconomic status, $78 \%$ of them are having moderate level. More than half of the patients are living in a normal marital status, in which the finding shows that $69 \%$ of them are married (Table 2 ).

Table I Socio-demographic characteristics of the diabetic patients

\begin{tabular}{|c|c|c|c|c|}
\hline No. & Characteristics & & $\mathbf{F}$ & $\%$ \\
\hline \multirow{6}{*}{ I } & \multirow{6}{*}{ Age group } & 30-39 year & 1 & 1 \\
\hline & & $40-49$ year & 17 & 17 \\
\hline & & 50-59 year & 30 & 30 \\
\hline & & $60-69$ year & $4 I$ & 41 \\
\hline & & $70 \leq$ year & 11 & 11 \\
\hline & & Total & 100 & 100 \\
\hline \multirow{3}{*}{2} & \multirow{3}{*}{ Gender } & Male & 73 & 73 \\
\hline & & Female & 27 & 27 \\
\hline & & Total & 100 & 100 \\
\hline \multirow{4}{*}{3} & \multirow{4}{*}{ Socioeconomic status } & Low & 5 & 5 \\
\hline & & Moderate & 78 & 78 \\
\hline & & High & 17 & 17 \\
\hline & & Total & 100 & 100 \\
\hline \multirow{6}{*}{4} & \multirow{6}{*}{ Marital status } & Unmarried & 0 & 0 \\
\hline & & Married & 69 & 69 \\
\hline & & Separated & 4 & 4 \\
\hline & & Divorced & 9 & 9 \\
\hline & & Widowed & 18 & 18 \\
\hline & & Total & 100 & 100 \\
\hline
\end{tabular}

Table 2 Medical characteristics of the diabetic patients

\begin{tabular}{|c|c|c|c|c|}
\hline No. & Characteristics & & $\mathbf{F}$ & $\%$ \\
\hline \multirow{7}{*}{ I } & \multirow{7}{*}{ Body mass index } & Underweight & 0 & 0 \\
\hline & & Normal weight & 0 & 0 \\
\hline & & Overweight & 28 & 28 \\
\hline & & Obesity I & 54 & 54 \\
\hline & & Obesity II & 17 & 17 \\
\hline & & Obesity III & I & I \\
\hline & & Total & 100 & 100 \\
\hline \multirow{3}{*}{2} & \multirow{3}{*}{ Smoking } & Yes & 76 & 76 \\
\hline & & No & 24 & 24 \\
\hline & & Total & 100 & 100 \\
\hline \multirow{3}{*}{3} & \multirow{3}{*}{ Consuming alcohol } & Yes & 18 & 18 \\
\hline & & No & 82 & 82 \\
\hline & & Total & 100 & 100 \\
\hline \multirow{4}{*}{4} & \multirow{4}{*}{$\begin{array}{l}\text { Cumulative average of } \\
\text { blood sugar }(\mathrm{HbAIC})\end{array}$} & Normal rate & 10 & 10 \\
\hline & & diabetes & 28 & 28 \\
\hline & & High rate & 62 & 62 \\
\hline & & Total & 100 & 100 \\
\hline \multirow{4}{*}{5} & \multirow{4}{*}{$\begin{array}{l}\text { Diagnosis date of } \\
\text { diabetes mellitus }\end{array}$} & Low & 31 & 31 \\
\hline & & Moderate & 32 & 32 \\
\hline & & High & 37 & 37 \\
\hline & & Total & 100 & 100 \\
\hline \multirow{3}{*}{6} & \multirow{3}{*}{$\begin{array}{l}\text { Following diet without } \\
\text { treatment }\end{array}$} & Yes & 9 & 9 \\
\hline & & No & 91 & 91 \\
\hline & & Total & 100 & 100 \\
\hline \multirow{3}{*}{7} & \multirow{3}{*}{ On tablets } & Yes & 73 & 73 \\
\hline & & No & 27 & 27 \\
\hline & & Total & 100 & 100 \\
\hline \multirow{3}{*}{8} & \multirow{3}{*}{ On insulin } & Yes & 18 & 18 \\
\hline & & No & 82 & 82 \\
\hline & & Total & 100 & 100 \\
\hline \multirow{3}{*}{9} & \multirow{3}{*}{ On herbs therapy } & Yes & 33 & 33 \\
\hline & & No & 67 & 67 \\
\hline & & Total & 100 & 100 \\
\hline \multirow{4}{*}{10} & \multirow{4}{*}{$\begin{array}{l}\text { Diagnosis date of } \\
\text { coronary heart occlusion }\end{array}$} & Low & 54 & 54 \\
\hline & & Moderate & 37 & 37 \\
\hline & & High & 9 & 9 \\
\hline & & Total & 100 & 100 \\
\hline \multirow{4}{*}{11} & \multirow{4}{*}{$\begin{array}{l}\text { Date of coronary artery } \\
\text { bypass graft surgery }\end{array}$} & Before 3 or 8 months & 40 & 40 \\
\hline & & Before 9 or 12 months & 32 & 32 \\
\hline & & More than 12 months & 28 & 28 \\
\hline & & Total & 100 & 100 \\
\hline
\end{tabular}


This table reveals that $54 \%$ of the patients have obesity class (I) according to body mass index; $76 \%$ of them are smoking cigarettes; and only $18 \%$ of them are consuming alcohol. The cumulative average of blood sugar test indicates more than seven (62\%) among the patients. The date of diabetes mellitus is more than ten years (37\%). $91 \%$ of the patients do not following a diet without treatment,
$73 \%$ of them are taking anti-diabetic tablets and $82 \%$ of them didn't take an insulin and herbal treatment (67\%) and only $33 \%$ take herbs as treatment. The diagnosis date of coronary heart occlusion is $1-5$ years $(54 \%)$ and the date of bypass graft surgery is before three or eight months ago $(40 \%)$ Table 3 .

Table 3 Food frequency questionnaire by diabetic patients $(\mathrm{N}=100)$

\begin{tabular}{|c|c|c|c|c|c|c|}
\hline \multicolumn{2}{|c|}{ Food frequency questionnaire } & \multirow{2}{*}{$\begin{array}{l}\text { Never } \\
5\end{array}$} & \multirow{2}{*}{$\begin{array}{l}\text { Sometimes } \\
46\end{array}$} & \multirow{2}{*}{$\begin{array}{l}\text { Always } \\
49\end{array}$} & \multirow{2}{*}{$\begin{array}{l}\text { M.S } \\
2.44\end{array}$} & \multirow{2}{*}{$\begin{array}{l}\text { Severity } \\
\mathrm{H}\end{array}$} \\
\hline Protein & Sheep meat $210 \mathrm{~g}$ boneless & & & & & \\
\hline & Beef meat $2 \mathrm{l} 0 \mathrm{~g}$ Boneless & 9 & 71 & 20 & 2.11 & M \\
\hline & Chicken $210 \mathrm{~g}$ Boneless & 5 & 19 & 76 & 2.71 & $\mathrm{H}$ \\
\hline & Fish $210 \mathrm{~g}$ & 4 & 43 & 53 & 2.49 & $\mathrm{H}$ \\
\hline & Eggs 50gm & 0 & 75 & 25 & 2.25 & M \\
\hline & Milk all kinds $100 \mathrm{ml}$ & 47 & 36 & 17 & 1.7 & M \\
\hline & Cream 50gm & 69 & 23 & 8 & 1.39 & L \\
\hline & Cooked cheese $250 \mathrm{~g}$ & 4 & 79 & 17 & 2.13 & M \\
\hline \multirow[t]{6}{*}{ Legume } & Lentils 90g amount (a small cup ) & 16 & 70 & 14 & 1.98 & M \\
\hline & Phaseolus 90grams (a small cup) & 26 & 65 & 9 & 1.83 & M \\
\hline & Pisum sativum 90g (a small cup) & 31 & 65 & 4 & 1.73 & M \\
\hline & Cicer arietinum 90g (a small cup) & 8 & 59 & 33 & 2.25 & M \\
\hline & Vigna 90g (a small cup) & 39 & 61 & 0 & 1.61 & L \\
\hline & Mung bean 2-6 90g (a small cup) & 82 & 18 & 0 & 1.18 & L \\
\hline \multirow[t]{5}{*}{ Grains } & Rice $120 \mathrm{~g}$ & 9 & 56 & 35 & 2.26 & M \\
\hline & Bread or loaf (wheat I20g) & 5 & 30 & 65 & 2.6 & $\mathrm{H}$ \\
\hline & Bread or loaf (hordeum I20g) & 5 & 42 & 53 & 2.48 & $\mathrm{H}$ \\
\hline & Bulgur I20g & 0 & 75 & 25 & 2.25 & M \\
\hline & Macaroni I20g & 32 & 41 & 27 & 1.95 & M \\
\hline \multirow[t]{5}{*}{ Nuts } & Almonds 90g & 0 & 70 & 30 & 2.3 & M \\
\hline & Walnuts 90gm & 30 & 54 & 16 & 1.86 & M \\
\hline & Pistacia vera $90 \mathrm{~g}$ & 10 & 60 & 30 & 2.2 & M \\
\hline & Cashew $9 \mathrm{gm}$ & 5 & 65 & 30 & 2.25 & M \\
\hline & Corylus $90 \mathrm{~g}$ & 44 & 40 & 16 & 1.72 & M \\
\hline \multirow[t]{9}{*}{ Fruits } & Apples I20g medium-sized & 4 & 34 & 62 & 2.58 & $\mathrm{H}$ \\
\hline & Banana I20g medium-sized & 37 & 51 & 12 & 1.75 & M \\
\hline & Orange $120 \mathrm{~g}$ medium-sized & 19 & 32 & 49 & 2.3 & M \\
\hline & Pomegranate I20g medium-sized & 10 & 48 & 42 & 2.32 & M \\
\hline & Lemon $120 \mathrm{~g}$ medium-sized & 5 & 34 & 61 & 2.56 & $\mathrm{H}$ \\
\hline & Peaches $120 \mathrm{~g}$ medium-sized & 30 & 53 & 17 & 1.87 & M \\
\hline & Citrus reticulate $120 \mathrm{~g}$ medium-sized & 18 & 52 & 30 & 2.12 & M \\
\hline & Grapefruit I20 medium-sized gm & 46 & 27 & 27 & 1.81 & M \\
\hline & Berry 120 grams & 0 & 46 & 54 & 2.54 & $\mathrm{H}$ \\
\hline
\end{tabular}


Table Continued....

\begin{tabular}{|c|c|c|c|c|c|c|}
\hline \multicolumn{2}{|c|}{ Food frequency questionnaire } & \multirow{2}{*}{$\begin{array}{l}\text { Never } \\
0\end{array}$} & \multirow{2}{*}{$\begin{array}{l}\text { Sometimes } \\
26\end{array}$} & \multirow{2}{*}{$\begin{array}{l}\text { Always } \\
74\end{array}$} & \multirow{2}{*}{$\begin{array}{l}\text { M.S } \\
2.74\end{array}$} & \multirow{2}{*}{$\begin{array}{l}\text { Severity } \\
\mathrm{H}\end{array}$} \\
\hline Vegetables & Tomato (One serving is $250 \mathrm{~g}$ ) & & & & & \\
\hline & Potato (250g per meal) & 0 & 40 & 60 & 2.6 & $\mathrm{H}$ \\
\hline & Cucumber (One serving is $250 \mathrm{~g}$ ) & 0 & 9 & 91 & 2.91 & $\mathrm{H}$ \\
\hline & Pepper ( $250 \mathrm{~g}$ per meal) & 5 & 32 & 63 & 2.58 & $\mathrm{H}$ \\
\hline & Brassica (One serving is $250 \mathrm{~g}$ ) & 19 & 47 & 34 & 2.15 & M \\
\hline & Broccoli (meal per 250g) & 70 & 17 & 13 & 1.43 & L \\
\hline & Turnip (One serving is $250 \mathrm{~g}$ ) & 38 & 49 & 13 & 1.75 & M \\
\hline & Carrot (One serving is $250 \mathrm{~g}$ ) & 15 & 68 & 17 & 2.02 & M \\
\hline & Eggplant (One serving is $250 \mathrm{~g}$ ) & 4 & 76 & 20 & 2.16 & M \\
\hline & Okra (One serving is $250 \mathrm{~g}$ ) & 0 & 70 & 30 & 2.3 & M \\
\hline & Garlic (20 grams per meal) & 13 & 35 & 52 & 2.39 & $\mathrm{H}$ \\
\hline & Onions (50 grams per meal) & 4 & 29 & 67 & 2.63 & $\mathrm{H}$ \\
\hline & Marrow (One serving is $250 \mathrm{~g}$ ) & 14 & 56 & 30 & 2.16 & M \\
\hline & Cabbage (One serving is $250 \mathrm{~g}$ ) & 5 & 69 & 26 & 2.21 & M \\
\hline & Leafy vegetables (basil, mint, , .... etc) $50 \mathrm{~g}$ & 0 & 14 & 86 & 2.86 & $\mathrm{H}$ \\
\hline \multirow[t]{4}{*}{ Fat } & Animal fat (fat free) spoon cup $5 \mathrm{ml}$ & 66 & 30 & 4 & 1.38 & L \\
\hline & Cups vegetable fat spoon $5 \mathrm{ml}$ & 83 & 17 & 0 & 1.17 & L \\
\hline & Olive oil cup $5 \mathrm{ml}$ & 18 & 58 & 24 & 2.06 & M \\
\hline & Palm oil cup $5 \mathrm{ml}$ & 0 & 23 & 77 & 2.77 & $\mathrm{H}$ \\
\hline \multirow[t]{14}{*}{ Fluids } & Water $500 \mathrm{ml}$ & 0 & 27 & 73 & 2.73 & $\mathrm{H}$ \\
\hline & Lemon juice $330 \mathrm{ml}$ & 48 & 26 & 26 & 1.78 & M \\
\hline & Pomegranate juice $330 \mathrm{ml}$ & 64 & 31 & 5 & 1.41 & L \\
\hline & Orange juice $330 \mathrm{ml}$ & 51 & 39 & 10 & 1.59 & L \\
\hline & Cocktail juice $330 \mathrm{ml}$ & 65 & 26 & 9 & 1.44 & L \\
\hline & Cola $330 \mathrm{ml}$ & 52 & 35 & 13 & 1.61 & L \\
\hline & Seven up $330 \mathrm{ml}$ & 23 & 54 & 23 & 2 & M \\
\hline & Miranda $330 \mathrm{ml}$ & 70 & 25 & 5 & 1.35 & L \\
\hline & Soda330ml & 46 & 37 & 17 & 1.71 & M \\
\hline & Diet $330 \mathrm{ml}$ & 10 & 42 & 48 & 2.38 & $\mathrm{H}$ \\
\hline & Carbonate with caffeine & 74 & 22 & 4 & 1.3 & L \\
\hline & Tea 30ml & 0 & 5 & 95 & 2.95 & $\mathrm{H}$ \\
\hline & Coffee $30 \mathrm{ml}$ & 10 & 51 & 39 & 2.29 & M \\
\hline & Cocoa 30ml & 52 & 44 & 4 & 1.52 & L \\
\hline \multirow[t]{5}{*}{ Botanical Herbs } & Cinnamon (students) I0g & 67 & 9 & 24 & 1.57 & L \\
\hline & Oliban I0g & 77 & 5 & 18 & 1.41 & L \\
\hline & Cyperus I0g & 62 & 0 & 38 & 1.76 & M \\
\hline & Ginger (race warm), I0g & 67 & 10 & 23 & 1.56 & $\mathrm{~L}$ \\
\hline & Hawthorn $10 \mathrm{~g}$ & 82 & 4 & 14 & 1.32 & L \\
\hline Total & & & & & 2.04 & $M$ \\
\hline
\end{tabular}

M.S, mean of score; Sig, significance; L, low; Moderate, H, high;

$($ Low $=$ I -1.66, Moderate $=1.67-2.33$, High=2.34-3)

Citation: Abdulhameed SM, Khudur KM.Assessment of food frequency for diabetic patients after coronary artery bypass graft at ibn al-bitar specialized center for cardiac surgery in Baghdad city. Nurse Care Open Acces J. 20 I8;5(I): I4-20. DOI: I0.15406/ncoaj.20I8.05.00 I I I 
This table shows the food frequent intakes by diabetic patients; up the protein nutrients, sheep meat, chicken, and fish are highly significant (M.S=2.44, 2.71, \& 2.49) while beef meat, eggs, milk, and cooked cheese are moderately significant except cream which has low significant among them. The legumes are moderately significant in all nutrients except vigna and mung bean which are low significant (M.S=1.61 \& 1.18). Regarding grains, most nutrient show moderate significant except bread of wheat and hordeum which are show high significant (M.S=2.60 \& 2.48). Nuts' nutrient items are show moderate significant in its entire item. The fruits show moderate significant $\mathrm{n}$ most of fruit's type except apples, lemons, and berry are highly significant (M.S $=2.58,2.56$, and 2.54). Vegetables reveal that are undertaking moderate to high; tomato, potato, cucumber, pepper, garlic, onions, and leafy vegetables are high significant intake by the patients while turnip, carrot, eggplant, okra, marrow, and cabbage are moderate significant except broccoli is show low significant among them. Regarding fat intake, palm oil is highly intake by the patients (M.S=2.77) and olive oil is moderately intake while animal fat and cups vegetables are low intake. Among fluid, water, diet drink, and tea are highly significant (M.S=2.73, 2.38, \&2.95), lemon juice, seven up, soda, and coffee are moderate significant but the other fluid are low significant. The botanical herbs are rarely intake by the patients which are revealed low significant except Cyperus which is moderately significant among them (M.S=1.76) Table 4.

Table 4 Association between dietary habits, food frequency questionnaire and age group of diabetic patients $(\mathrm{N}=100)$

\begin{tabular}{llll}
\hline Age & Moderate & High & Total \\
\hline $30-39$ year & 1 & 0 & 1 \\
$40-49$ year & 17 & 0 & 17 \\
$50-59$ year & 26 & 4 & 30 \\
$60-69$ year & 41 & 0 & 41 \\
$70 \leq$ year & 11 & 0 & 11 \\
Total & 96 & 4 & 100 \\
$\chi^{2}$ obs $=9.722 \mathrm{df}=4 \chi^{2}$ crit. $=9.49$ & $P \leq 0.05$ Sig. $=\mathrm{S}$ &
\end{tabular}

This table shows that highly significant differences association between age group with knowledge of the dietary habits and food frequency questionnaire Table 5 . This table shows that no significant association between socioeconomic status and dietary habits and food frequency questionnaire Table 6. The table above shows that high significant differences association between marital statuses dietary habits, food frequency which are more frequent among married patients Table 7 .

Table 5 Association between dietary habits food frequency questionnaire and socioeconomic status among diabetic patients $(\mathrm{N}=100)$

\begin{tabular}{llll}
\hline \multicolumn{1}{c}{ FFQ } & Moderate & High & Total \\
\hline Locioeconomic & 5 & 0 & 5 \\
Moderate socioeconomic & 75 & 3 & 78 \\
High socioeconomic & 16 & 1 & 17 \\
Total & 96 & 4 & 100 \\
$\chi^{2}$ obs. $=0.370 \mathrm{df}=2 \chi^{2}$ crit. $=5.99$ & $P \leq 0.05$ Sig. $=$ N.S & & \\
\end{tabular}

Table 6 Association between dietary habits and food frequency questionnaire with marital status of diabetic patients $(\mathrm{N}=100)$

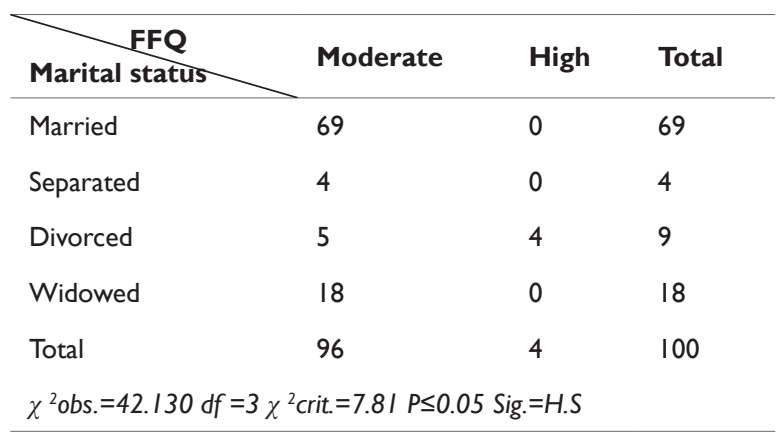

\section{Discussion}

\section{Part I: Discussion of the socio-demographic characteristics of studied sample}

Through the data analysis of distribution of the socio-demographic shows in Table 1 that the more frequent age groups are (60-69) years old among the patients (41\%). This results were similar a study done by Pertti et al. ${ }^{6}$ who indicate that $(46.9 \%)$ of the sample were less than 65 years old. The variables reveal that most of the samples were males $(73 \%)$. This results were similar to a study done by Pertti et al. ${ }^{7}$ who showed that $(79.1 \%)$ of patients were males. But these results disagreed with Smeltzeret al. ${ }^{8}$ who stated that women have higher incidence of coronary artery disease and more exposed for CABG surgery. Regarding socioeconomic status, $78 \%$ of them are having moderate level (71-86). This results disagrees with a study done by Abbas $^{9}$ who found that $(87.8 \%)$ of patients were in a low economic status. This also disagrees with Nateghian ${ }^{10}$ who reported that patients with low economic status are at risk of coronary artery disease. More than half of the patients are living in a normal marital status, in which the finding shows that $69 \%$ of them are married, this result is similar to the study, by Noha et al. ${ }^{11}$ who found that $(84.2 \%)$ of the sample were married.

\section{Part II: discussion of the medical characteristics of studied sample.}

The medical characteristics of the patients in part two reveal that Table $254 \%$ of the patients have obesity class one; (30.0-34.9) according to the body mass index this results were similar to a study done by Yap ${ }^{12}$ who reported that the age group (60-69) years with the highest prevalence of obesity. The search for smokers is $76 \%$ of the total sample result. This findings agrees with $\mathrm{Abbas}^{9}$ who found that $(80 \%)$ of patients were smokers and Wang et al. ${ }^{13}$ who showed that $(59.1 \%)$ of the sample are smoked. But this result disagrees with Helen where findings uncovered that approximately (88\%) of sample were not smokers. Regarding of alcohol only $18 \%$ of them consumed alcohol this ratio is acceptable in the Muslim countries compared to other communities in which to disagree from drinking alcohol (the researcher). The cumulative average of blood sugar test (HbAlc) indicates more than seven (62\%) among the patients because the glucose level is affected by several factors, such as the psychological situation, nutritional status, and physical factors (the researcher).

\section{Part III: discussion of the food frequent questionnaire characteristics of studied sample.}

This part show the food frequent questionnaire by diabetic patients 
Table 3 the protein nutrients, sheep meat, chicken, and fish are highly significant with diabetes appears because they are food items to help patients with diabetes and do not affect the muscular effort of the heart and are easily metabolic in the body while beef, eggs, milk, and cheese are relatively acceptable except cream which has low significant among them because it affects directly on the cardiac arteries, as well as diabetes. Reveal that the legumes are moderately significant (acceptable) because it is available it easier for everyone dealt with it does not directly affect the diabetic patients who Coronary Artery bypasses Graft the grains, most nutrient show moderate significant except bread of wheat and barley which are show high significant because the most of the patients who rely on these foods in our daily lives reveal that the nuts' nutrient items are show moderate significant in its entire item because they contain omega-3 ingredients that help improve circulation and give energy to people with diabetes also the fruits show moderate significant in most of fruit's type except apples, lemons, and berry are highly significant most available, and prices suitable for everyone as well as its benefits for patients reveal that Vegetables reveal that are undertaking moderate to high; tomato, potato, cucumber, pepper, garlic, onions, and leafy vegetables are high significant intake by the patients because it is cheap and beneficial for patients this vegetable is unfavorable when people, especially cardiac disease patients while turnip, carrot, eggplant, okra, marrow, and cabbage are moderate significant except broccoli is show low significant among them unknown to most people, and a little availability the fluid, water, diet drink, and tea are highly significant, it does not harm the health of the body and the habits of the people in these areas to allow taking it at any time lemon juice, seven up, soda, and coffee are moderate significant but the other fluid are low significant being hurt directly to patients the fat intake, palm oil is highly intake by the patients and olive oil is moderately intake while animal fat and cups vegetables are low intake, this result is identical to the instructions of the physician of patients with diabetes and patients with C.A.B.G. the botanical herbs are rarely intake by the patients which are revealed low significant except cyperus which is moderately significant among them, Herbs in general is slow and preventive treatments and patients generally need quick fixes hits in addition it is weak in the culture of our society (the researcher).

Regarding Table 4 the dietary habits and food frequency questionnaire are more frequently held by patients with age group (60-69) years; the indicates high significant association between age group and dietary habits, food frequency questionnaire because the old age usually need most to the quality of food will help them to overcome the deficits they face as well as concern for the health after C.A.B.G. (the researcher).

Table 5 shows that dietary habits and food frequency questionnaire are more frequent among those who are moderate level of socioeconomic status; but the table indicates that there is no significant association between socioeconomic status with both dietary habits and food frequency questionnaire (the researcher). ${ }^{14}$

The Table 6 indicates that dietary habits and food frequency questionnaire are associated with married patients; the table indicates high significant association between marital status with dietary habits and food frequency questionnaire because the married constitute the majority from among (69\%), the study similar to the Kari et al. ${ }^{15}$ who showed that $(68.4 \%)$ of study sample were married.

\section{Conclusion}

Reveals the study sample to those (eating three meals, eating salad vegetables with every meal, and drink more water) as positive habits moral high food held by diabetic patients the results indicate highly significant differences association between age group with knowledge of the dietary habits. There is indicated that high significant association between marital status and dietary habits high significant differences association between marital statuses food frequency which are more frequent among married patients

\section{Recommendation}

Diabetes self-management education (DSME) and support (DSMS) programs are appropriate for education and support to develop and maintain behaviors that can prevent or delay the onset of diabetes, Diabetes self-management education (DSME) and support (DSMS) programs are appropriate for education and support to develop and maintain behaviors that can prevent or delay the onset of diabetes, Screening for and treatment of modifiable risk factors for cardiovascular disease is suggested follow-up for counseling may be important for health, Perform the A1C test at least two times a year in patients who are meeting treatment goals (and who have stable glycemic control), Activating the role of nutrition Nutrition Research Institute at the National Centers for diabetes about diet programs for patients with diabetes, In adults, a screening lipid profile is reasonable at the time of first diagnosis, at the initial medical evaluation twice yearly.

\section{Acknowledgements}

None.

\section{Conflict of interest}

The author declares no conflict of interest.

\section{References}

1. Kushner FG, O'Gara PT, Ascheim DD, et al. 2013 ACCF/AHA guideline for the management of ST-elevation myocardial infarction: a report of the American college of cardiology foundation/American heart association task force on practice guidelines. Circulation. 2013;127(4):e362-425.

2. Sarwar N, Gao P, Seshasai SR, Gobin R, et al. Diabetes mellitus, fasting blood glucose concentration, and risk of vascular disease: A collaborative meta-analysis of 102 prospective studies. Lancet. 2010;375(9733):22152222 .

3. Abraham G Thomas. Food and Nutrition for Nurses Christian Medical College \& Hospital. Ludhiana, Punjab, India: Jaypee Brothers Medical Publishers; 2012. p. 8-12.;

4. Koochemeshki V, Salmanzadeh HR, Sayyadi H, et al. The effect of diabetes mellitus on short term mortality and morbidity after isolated coronary artery bypass grafting surgery. Int Cardiovasc Res $J$. 2013;7(2):41-45.

5. John Betteridge and Stephen Nicholls. Managing Cardiovascular Complications in Diabetes. USA: John Wiley, Sons; 2014.

6. Pertti Loponen, Micael Luther, Jan-Ola Wistbaka, et al. Quality of life during 18 months after coronary artery bypass grafting. Eur $J$ Cardiothorac Surg. 2007;32(1):77-82.

7. Pertti Loponen, Micheal Luther, Juha Nissinen, et al. EuroSCORE predicts health-related quality of life after coronary artery bypass grafting. Interact Cardiovasc Thorac Surg. 2008;7(1):564-568.

8. Smeltzer SC, Bare B, Hinkle JL. Brunner and Suddarth's Textbook of Medical - Surgical Nursing. 12th ed. Philadelphia: Lippincott Williams and Wilkins Company; 2010;28(687):756-786. 
9. Abbas B Mohammed. Assessment of Stressful Life Events of Adult Patients with Ischemic Heart Disease in Baghdad City. College of Nursing/University of Baghdad, Iraq: Springer; 2012. p. 55-57.

10. Nateghian S. Mental health and stressful life events in coronary hear disease patients and non- patients. Iranian Journal of Psychiatry. 2008;3(2):71-74.

11. Noha El Baz, Berrie M, Jitse $P$, et al. Coronary artery bypass graft (CABG) surgery patients in a clinical pathway gained less in health-related quality of life as compared with patients who undergo CABG in a conventionalcare plan. Journal of Evaluation in Clinical. 2009;15(3):498-505.
12. Yap C, Mohajeri M, Yii M. Obesity and early complications after cardiac surgery. Med J Aust. 2007;186(7):350-354

13. Wang J, Xiao F, Li Y, et al. Risk factors for operative mortality in 1098 patients with coronary artery bypass grafting surgery: a single center report. Beijing Da Xue Xue Bao. 2011;43(1):134-139.

14. Kinley Mc. Macronutrients: the Importance of Carbohydrate, Protein, and Fat. Health Center; 2014.

15. Kari Hanne Gjeiilo, Alexander Wahba, Pal Klepstad, et al. Survival and quality of life in an elderly cardiac surgery population: 5-year follow-up. Eur J Cardiothorac Surg. 2013;44(1):182-188. 